\title{
Rituximab Therapy for Refractory Autoimmune Thrombocytopenia in Patients with Systemic Lupus Erythematosus
}

\section{Sistemik Lupus Eritematozus'lu Refrakter Otoimmun Trombositopenili Hastada Rituximab Tedavisi}

\author{
Didem Atay ${ }^{1}$, Gülyüz Öztürk², Sema Anak², Ömer Devecioğlu², Ayşegül Ünüvar², \\ Zeynep Karakaş², Leyla Ağaoğlu² \\ ${ }^{1}$ Okmeydani Education and Research Hospital, Department of Pediatric Hematology and Oncology, İstanbul, Turkey \\ ${ }^{2}$ Istanbul University, Istanbul School of Medicine, Department of Pediatric Hematology, Oncology, BMT, İstanbul, Turkey
}

\section{To the Editor,}

Systemic lupus erythematosus (SLE) and autoimmune polyendocrinopathy are characterized by autoantibodies against a variety of target organs. Traditional treatment strategies for immune cytopenias include global immunosuppression that targets both the humoral and cell-mediated arms of the immune system. B-cells play an important role in the pathogenesis of many autoimmune diseases. Targeted depletion of B-lymphocytes is an alternative treatment approach for autoimmune disorders. Rituximab-a chimeric, human $\operatorname{IgG} 1_{\mathrm{K}}$ monoclonal antibody-is specific for the CD20 antigen and can selectively deplete B-cells via antibody-dependent cell-mediated cytotoxicity, complement-mediated cytotoxicity, and inhibition of cell proliferation with direct induction of B-cell apoptosis. Several studies have shown the efficacy and safety of rituximab in the treatment of autoimmune disorders [1-5].

Herein we describe a 16-year-old male with SLE-associated hemophagocytic syndrome (HPS), autoimmune hemolytic anemia (AIHA), and thrombocytopenia (AITP), as well as recurrent profound thrombocytopenia refractory to glucocorticosteroids, intravenous immune globulin (IVIG) therapy, mycophenolate mofetil (MMF), and plasmapheresis. Four years after initially presenting with SLE, the patient was admitted to our hematology department with severe thrombocytopenia and anemia; the hemoglobin level was $8.5 \mathrm{~g} \mathrm{dL}^{-1}$, the white blood cell count (WBC) was $5000 \mathrm{~mm}^{-3}$, and the platelet (PLT) count was 3000 $\mathrm{mm}^{-3}$. Poikilocytosis, anisocytosis, schistocytosis, spherocytosis, target cells, and few thrombocytes were observed in the blood smear. Lactate dehydrogenase was elevated (446 U L ${ }^{-1}$ ) and the reticulocyte count was $1.07 \%$. Direct antiglobulin test was $1(+)$ for complement $(\mathrm{C} 3 \mathrm{~d})$ and $\operatorname{IgG}$. C3 and C4 levels were decreased to 0,26 g/l and $<0,10$ $\mathrm{g} /$. Antinuclear antibodies and anti-double stranded DNA antibodies were noted. Urinalysis showed urinary protein excretion of $2 \mathrm{~g} \mathrm{~d}^{-1}$.

Renal biopsy could not be performed because of thrombocytopenia. Bone marrow aspiration showed elevated histiocytes with evidence of hemophagocytosis. The patient was therefore diagnosed as SLE-associated HPS, AIHA, and AITP, and was treated with IVIG $\left(0.4 \mathrm{~g} \cdot \mathrm{kg}^{-1} \cdot \mathrm{d}^{-1}\right.$ for $5 \mathrm{~d})$ and methylprednisolone $\left(1 \mathrm{~m} \mathrm{~g} \cdot \mathrm{kg}^{-1} \cdot \mathrm{d}^{-1}\right)$, but severe thrombocytopenia persisted (PLT count: $7000 \mathrm{~mm}^{-3}$ ). Pulse steroid ( $1 \mathrm{~g} \mathrm{~d}^{-1}$ dieb. alt.) and plasmapheresis (6 times) were administered, but the patient did not respond (PLT count: $8000 \mathrm{~mm}^{-3}$ ). With MMF therapy (400 mg $\mathrm{m}^{-2}$ b.i.d.) the PLT count increased to $163,000 \mathrm{~mm}^{-3}$, but decreased again to $1000 \mathrm{~mm}^{-3}$ after 3 months. Despite

Address for Correspondence: Didem ATAY, M.D.,

Kartaltepe Mahallesi Dost Sokak Motif Apt. No: 5 D: 1134414 Bakırköy, İstanbul, Turkey

Phone: +90 21222177 77/5740 E-mail: didematay@hotmail.com

Received/Gelis tarihi : July 5, 2011

Accepted/Kabul tarihi : September 19, 2011 
repeated high-dose steroid and IVIG treatment together with MMF, a permanent response was not achieved.

Chronic corticosteroid treatment subsequently led to growth retardation, osteoporosis, hypertension, glaucoma, and myopathy. Due to the side effects of corticosteroids a slow tapering of oral steroids was started. Only two weeks later, he relapsed again with severe thrombocytopenia. After written informed consent was obtained from the family, rituximab $375 \mathrm{mg} \mathrm{m}^{-2}$ QWK was started (in total, 4 doses $)$. Chlorpheniramine $\left(0.02 \mathrm{mg} \mathrm{kg}^{-1}\right.$ i.v. $)$ and paracetamol (10 $\mathrm{mg} \mathrm{kg}^{-1}$ p.o.) were administered $15 \mathrm{~min}$ prior to each rituximab infusion. This was well tolerated and the PLT count recovered to $240,000 \mathrm{~mm}^{-3}$ after 4 weeks of the treatment $\left(10,500 \mathrm{~mm}^{-3}\right.$ after 1 week, 84,000 $\mathrm{mm}^{-3}$ after 2 week, and $80,000 \mathrm{~mm}^{-3}$ after 3 weeks (Table $1)$.

At the time this manuscript was written the patient had been in remission for 49 months. The patient exhibited slow regeneration of peripheral B-cells (total number of CD19 and 20 cells)—although with subnormal counts-49 months after treatment, and he was being maintained on a regimen of MMF and methylprednisolone for lupus nephritis. The patient did not require immunoglobulin substitution due to rituximab therapy. To date, infectious complications have not been observed.

The efficiency of rituximab in patients with childhoodonset SLE and severe autoimmune cytopenia has been reported in a variety of series and case reports [6-8]. The drug was generally well tolerated; most children with AIHA or AITP remained disease-free. Treatment-related toxicity is primarily due to infusion-related events. In the presented case rituximab therapy was successful in treating autoimmune cytopenias, but SLE remained active, as lupus nephritis and cutaneous lupus. As such, the persistence of rituximab's effectiveness in treating SLE remains unclear. In conclusion, rituximab therapy shows promise as an alternative to intensive immunosuppressive therapy

Table 1: Hemoglobin and Thrombocyte Levels During Rituximab Therapy

\begin{tabular}{|c|c|c|} 
Week & $\begin{array}{c}\text { Hemoglobin level } \\
\left(\mathrm{g} \mathrm{dL}^{-1}\right)\end{array}$ & $\begin{array}{c}\text { Thrombocyte level } \\
\left(\mathrm{mm}^{-3}\right)\end{array}$ \\
\hline 1 & 8.8 & 10,500 \\
\hline 2 & 8.6 & 84,000 \\
\hline 3 & 8.0 & 80,000 \\
\hline 4 & 8.0 & 240,000 \\
\hline
\end{tabular}

and splenectomy in children with autoimmune cytopenias that are resistant to first-line therapy and cyclosporin/ MMF. In cases of the recurrence of thrombocytopenia or anemia, a second treatment course is feasible and may successfully control the disease. Additional research is necessary to better understand the role of rituximab in this patient population.

\section{Conflict of Interest Statement}

The authors of this paper have no conflicts of interest, including specific financial interests, relationships, and/ or affiliations relevant to the subject matter or materials included.

\section{References}

1. Kazkaz H, Isenberg D: Anti B cell therapy (rituximab) in the treatment of autoimmune diseases. Curr Opin Pharmacol. 2004; 4(4):398-402 Review.

2. Mantadakis E, Danilatou V, Stiakaki E, Kalmanti M: Rituximab for refractory Evans syndrome and other immune-mediated hematologic diseases. Am J Hematol 2004; 77 (3): 303-310

3. Zecca M, Nobili B, Ramenghi U, Perrotta S, Amendola G, Rosito P, Jankovic M, Pierani P, De Stefano P, Bonora MR, Locatelli F: Rituximab for the treatment of refractory autoimmune hemolytic anemia in children. Blood 2003; 101: 3857-3861

4. Rao A, Kelly M, Musselman M, Ramadas J, Wilson D, Grossman W, Shenoy S: Safety, efficacy and immune reconstitution after rituximab therapy in pediatric patients with chronic or refractory hematologic autoimmune cytopenias. Pediatr Blood Cancer 2008; 50: 822-825

5. Bennett CM, Rogers ZR, Kinnamon DD, Bussel JB, Mahoney DH, Abshire TC, Sawaf H, Moore TB, Loh ML, Glader BE, McCarthy MC, Mueller BU, Olson TA, Lorenzana AN, Mentzer WC, Buchanan GR, Feldman HA, Neufeld EJ: Prospective phase 1/2 study of rituximab in childhood and adolescent chronic immune thrombocytopenic purpura. Blood 2006; 107: 2639-2642

6. Robak T: Monoclonal antibodies in the treatment of autoimmune cytopenias. Eur J Haematol 2004; 72: 79-88

7. Kumar S, Benseler SM, Allen MK, Silverman ED: B-cell depletion for autoimmune thrombocytopenia and autoimmune hemolytic anemia in pediatric systemic lupus erythematosus. Pediatrics 2009; 123 (1): 159-163

8. Willems M, Haddad E, Niaudet P, Koné-Paut I, Bensman A, Cochat P, Deschênes G, Fakhouri F, Leblanc T, Llanas B, Loirat C, Pillet P, Ranchin B, Salomon R, Ulinski T, BaderMeunier B; French Pediatric-Onset SLE Study Group: Rituximab therapy for childhood-onset systemic lupus erythematosus. J Pediatr 2006; 148 (5): 623-627 